\title{
Effects of slowed gastrointestinal motility on levodopa pharmacokinetics
}

\author{
Nélida Fernández *, Juan J. García, M. José Diez, Ana M. Sahagún, Aranzazu González, \\ Raquel Díez, Matilde Sierra \\ Area de Farmacologia, Instituto de Biomedicina, Universidad de Leon, 24071, Leon, Spain
}

\section{A R T I C L E I N F O}

\section{Article history:}

Received 1 October 2009

Received in revised form 2 March 2010

Accepted 23 March 2010

\section{Keywords:}

Biperiden

Levodopa

Pharmacokinetics

Rabbits

Slowed gastrointestinal motility

\begin{abstract}
A B S T R A C T
Autonomic disorders are often seen in Parkinson's disease, with disturbances of the gastrointestinal tract occurring most frequently. These disorders, mainly a delay in gastric emptying and slowed gastrointestinal motility, can modify the pharmacokinetics and effectiveness of drugs used to treat Parkinson's disease and administered orally. In this study, we evaluated in a rabbit model the pharmacokinetics of levodopa (administered with carbidopa) in the context of gastrointestinal motility slowed by the administration of an anticholinergic drug. Levodopa + carbidopa $(20: 5 \mathrm{mg} / \mathrm{kg})$ and the anticholinergic biperiden $(100 \mu \mathrm{g} / \mathrm{kg})$ were orally administered to rabbits over one of two time periods ( 7 or 14 days) to verify the stabilization of levodopa concentrations. The values of the area under the curve (AUC) and $C_{\max }$ were higher on the final day of treatment with an increase in AUC of $25 \%$ on day 7 and $33.4 \%$ on day 14 ; for $C_{\max }$, the increase was $15 \%$ on day 7 and $12.8 \%$ on day 14 . The values of AUC and $C_{\max }$ were lower than those obtained when levodopa was administered to rabbits with normal gastrointestinal motility. The values obtained for $C_{\min }$ (baseline sample obtained before administration) also increased with treatment duration (24\% and $47.4 \%$ on days 7 and 14, respectively). These values were higher than those obtained in the absence of anticholinergic administration. We conclude that, under our experimental conditions of slowed gastrointestinal motility, levodopa absorption diminishes, and final concentrations and $C_{\min }$ are higher than under conditions of normal motility.
\end{abstract}

(c) 2010 Elsevier B.V. All rights reserved.

\section{Introduction}

Parkinson's disease remains one of the most common neurodegenerative disorders, affecting $1 \%$ of the population over age 65 (Wilk and Lash, 2007). Autonomic disorders are often seen in idiopathic Parkinson's, especially in the advanced stages of the disease. Disturbances of the gastrointestinal tract are the most frequent autonomic disorders, including abnormal salivation, difficulty in swallowing (dysphagia), early feeling of satiety (abdominal bloating-distension), disorders of gastric emptying, and constipation (Korczyn, 1989; Edwards et al., 1993). These symptoms may affect the quality of life of patients with Parkinson's and modify the pharmacokinetics as well as the effectiveness of drugs used to treat this disease.

Levodopa (usually combined with carbidopa) is the most frequently used medication for treating Parkinson's. This drug is absorbed in the duodenum, jejunum and proximal ileum and metabolized to dopamine through decarboxylation in the stomach (Nutt and Fellman, 1984); thus, the rates of gastric emptying and gastrointestinal motility are important variables that may affect the amount of drug absorbed. Some fluctuations in clinical response in the context of motor performance (e.g., wearing-

\footnotetext{
* Corresponding author. Tel.: + 349872915 28; fax: + 34987291252. E-mail address: nelida.fernandez@unileon.es (N. Fernández).
}

off and on-off) are that patients with advanced Parkinson's disease experience are partially related to the peripheral pharmacokinetics of levodopa (Bredberg et al., 1990; Kempster et al., 1989; Shoulson et al., 1975).

Age-related delayed gastric emptying, dietary factors, variable transit time, and erratic absorption of the drug at the proximal intestine are some of the contributing factors to the decreased bioavailability of levodopa, leading to unpredictable patterns of motor fluctuation (Hardoff et al., 2001). In addition, these motor response fluctuations can be improved by bypassing the stomach via a non-oral administrative route, such as delivering levodopa directly into the small intestine or intravenously (Mouradian et al., 1990; Nyholm et al., 2003).

In this study, we evaluated the pharmacokinetics of levodopa (administered with carbidopa) under conditions of slowed gastrointestinal motility, a frequent scenario for patients with Parkinson's. To verify the stabilization of levodopa concentrations, we administered the treatment for two different periods of time, 7 or 14 days.

To reduce gastrointestinal motility and produce conditions that lead to constipation, we administered biperiden in a rabbit model. Biperiden is an antimuscarinic anticholinergic drug used in the symptomatic treatment of parkinsonism including the alleviation of the extrapyramidal syndrome induced by drugs, such as phenothiazines, but, like other antimuscarinics, is of no value against tardive dyskinesias. Anticholinergics may decrease the amount of levodopa absorbed by 
delaying gastric emptying and therefore increasing the metabolism of levodopa, but we have not found any study about the interaction between levodopa and biperiden.

\section{Materials and methods}

For this study, we used 12 healthy New Zealand white rabbits weighing 2.94 to $3.28 \mathrm{~kg}$. The animals were housed in individual metal cages, which allowed the isolation of faeces in a lower container to avoid coprophagia. The environmental conditions were humidity $(55 \pm 10 \%)$, temperature $\left(19 \pm 2{ }^{\circ} \mathrm{C}\right)$, and a $12 \mathrm{~h}$ light-12 h dark cycle. Rabbits were maintained under these conditions at least one week before the assay, with free access to water and standard laboratory chow.

The rabbits were randomly divided into two groups of six rabbits each. Both groups of animals received orally $20: 5 \mathrm{mg} / \mathrm{kg}$ levodopa + carbidopa (Sinemet ${ }^{\circledR}$ ) and $100 \mu \mathrm{g} / \mathrm{kg}$ biperiden (Akineton ${ }^{\circledR}$ ) daily for 7 days (Group 1 ) or 14 days (Group 2 ).

The drugs were administered dispersed in water by gastric intubation every morning at the same hour. A total of $50 \mathrm{ml}$ water was used for administration and cannula cleaning.

The first (day 1 ) and the last day (day 7 or 14 , respectively) of treatment, levodopa concentrations were determined at different
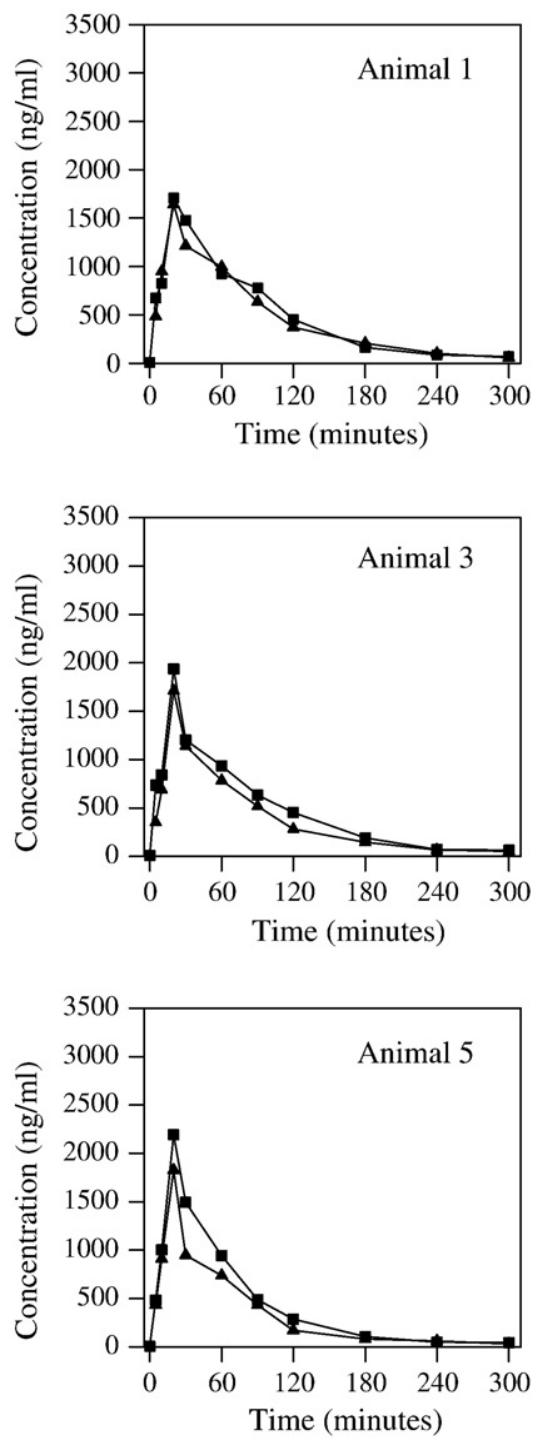

sampling times after drug administration. To obtain blood samples, we anaesthetized the rabbits with sodium pentobarbital $(30 \mathrm{mg} / \mathrm{kg}$ body weight, i.v.) and cannulated the left carotid artery with a silicone catheter (Silastic medical-grade tubing, $1.02 \mathrm{~mm}$ inner diameter $\times 2.16 \mathrm{~mm}$ outer diameter). Drug administration was carried out following the achievement of total recovery from anaesthesia. Blood samples $(3 \mathrm{ml}$ ) were obtained from the left carotid artery through the cannula into heparinised containers, immediately before and at 5, 10, $20,30,60,90,120,180,240$, and 300 min after administration.

To study the evolution of the maximum and minimum concentrations through the study, we obtained two blood samples from the marginal ear vein: immediately before $\left(C_{\min }\right)$ and at 20 min after drug administration $\left(C_{\max }\right)$ on days 3 and 5 (7-day treatment) and on days $3,6,9$, and 11 (14-day treatment).

Immediately after blood sample collection, plasma was separated by centrifugation and stored at $-20^{\circ} \mathrm{C}$ until analysis.

Levodopa extraction from plasma samples was carried out by using a catecholamine kit $\left(\right.$ Chromsystems ${ }^{\circledR}$ ) and was quantified by HPLC with electrochemical detection following the method described by Cummings et al., in 1990, slightly modified.

The mobile phase consisted of $50 \mathrm{mM}$ sodium dihydrogen phosphate buffer adjusted to $\mathrm{pH} 2.9$ with $1 \mathrm{M}$ orthophosphoric acid containing $250 \mathrm{mg} / \mathrm{l}$ heptanesulphonic acid and $80 \mathrm{mg} / \mathrm{l}$ EDTA and
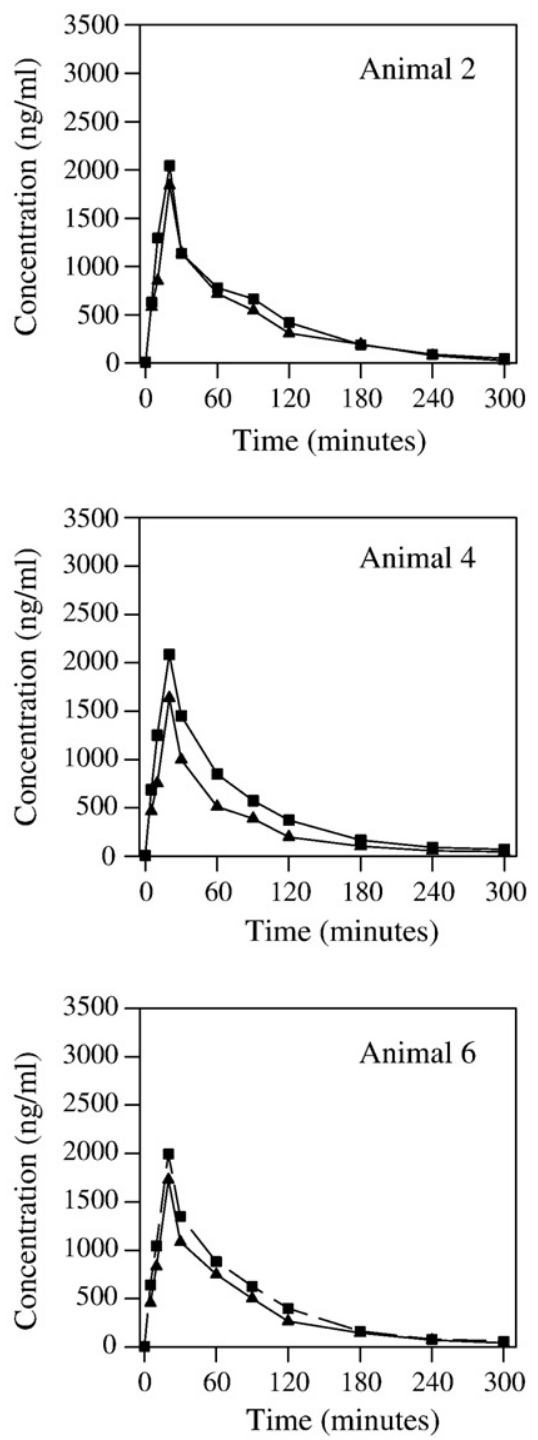

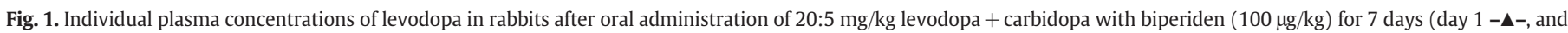
day $7-\square-)$. 
methanol $(90: 10, v / v)$. This mobile phase was pumped at a flow rate of $1 \mathrm{ml} / \mathrm{min}$.

The analytical column was a $25 \mathrm{~cm} \times 4.6 \mathrm{~mm}$ I.D. stainless-steel column, packed with Spherisorb ODS-2 (5 pm particle size, Waters Chromatography SA, Madrid, Spain) and the potential applied was $500 \mathrm{mV}$. Interday and intraday accuracy and precision were within $10 \%$ and neither heparin nor pentobarbital interfered with the assay.

\subsection{Pharmacokinetic studies}

Pharmacokinetic analysis was performed based on a noncompartmental description of the data observed.

Maximum plasma levodopa concentration $\left(C_{\max }\right)$ and the time to reach maximum concentration $\left(t_{\max }\right)$ were read directly from the individual plasma concentration-time curves.

The WinNonlin ${ }^{\circledR}$ computer program and formulae described by Gibaldi and Perrier (1982) were used to calculate the modelindependent pharmacokinetic parameters. These parameters were the elimination rate constant $(\lambda)$, the area under the plasma concentrationtime curve (AUC), the clearance $(\mathrm{Cl} / \mathrm{F})$, the volume of area $\left(V_{\mathrm{a}} / \mathrm{F}\right)$, the volume of distribution at steady state $\left(V_{s S} / F\right)$, the half-life associated with the $\lambda$ phase $\left(t_{1 / 2 \lambda}\right)$, the area under the first moment curve (AUMC), and the mean residence time (MRT).

The fraction of levodopa absorbed (F\%) was calculated by dividing the mean AUC by the value of the mean intravenous AUC obtained in a previous study (Garcia et al., 2005).

\subsection{Statistical evaluation}

All pharmacokinetic parameters were calculated for each animal and presented as arithmetic mean \pm standard deviation (mean \pm SD). Data were analysed using the Skewness test (to determine the normality) and Cochran test (to determine the uniformity of the variance).

When the data were normal and there was uniformity in the variance, the $t$-test was used to evaluate differences between days 1 and 7 and between days 1 and 14 . When the data were not normal and/or there was not uniformity in the variance, Wilcoxon test was employed.

To evaluate differences in $C_{\min }$ and $C_{\max }$ analysis of variance (ANOVA) was carried out and the Duncan's test was used to determine differences between data sets. When the data were not normal or there was not a uniformity in the variance, Kruskal-Wallis test was used, and when the results were significant, Wilcoxon test was used to assess differences between data sets. $P \leq 0.05$ was used as the level of significance for all analyses.

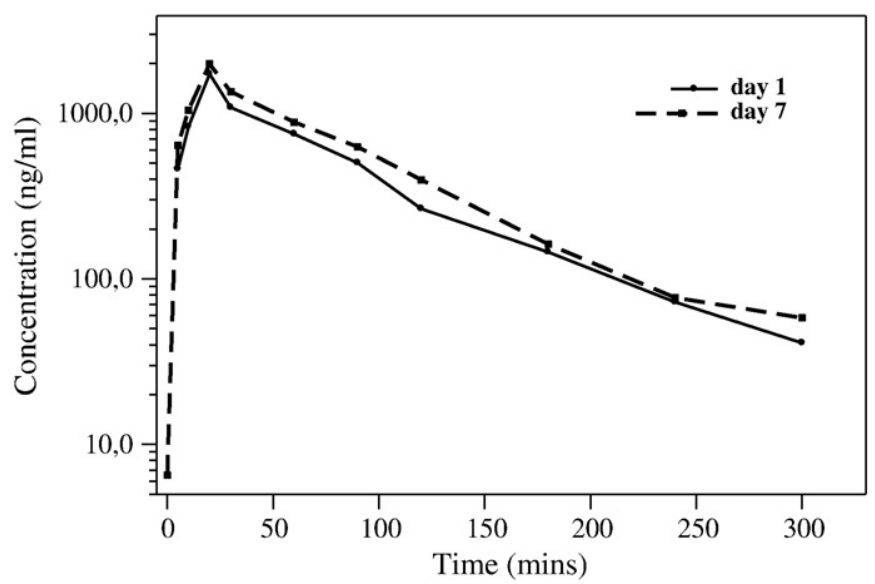

Fig. 2. Mean plasma concentrations of levodopa in rabbits after oral administration of $20: 5 \mathrm{mg} / \mathrm{kg}$ levodopa + carbidopa with biperiden $(100 \mu \mathrm{g} / \mathrm{kg})$ for 7 days.
Table 1

Pharmacokinetic parameters obtained by non-compartmental analysis in rabbits $(n=6)$ after oral administration of $20: 5 \mathrm{mg} / \mathrm{kg}$ levodopa/carbidopa and biperiden $(100 \mu \mathrm{g} / \mathrm{kg})$ for 7 days.

\begin{tabular}{|c|c|c|c|c|}
\hline \multirow[t]{2}{*}{ Parameters } & \multicolumn{2}{|l|}{ Day 1 of 7} & \multicolumn{2}{|l|}{ Day 7} \\
\hline & $\bar{X} \pm s$ & CV (\%) & $\overline{\bar{X}} \pm s$ & CV (\%) \\
\hline$\lambda\left(\min ^{-1}\right)$ & $0.0109 \pm 0.0041$ & 38.52 & $0.0083 \pm 0.0020$ & 16.34 \\
\hline AUC $\left(\mu \mathrm{g} \min \mathrm{ml}^{-1}\right)^{\mathrm{a}}$ & $115.64 \pm 15.47$ & 13.38 & $144.50 \pm 6.70$ & 4.64 \\
\hline$C_{\max }\left(\mu \mathrm{ml}^{-1}\right)^{\mathrm{a}}$ & $1.73 \pm 0.08$ & 5.07 & $1.99 \pm 0.16$ & 8.24 \\
\hline$t_{\max }(\min )$ & $20.00 \pm-$ & - & $20.00 \pm-$ & - \\
\hline $\mathrm{Cl} / \mathrm{F}\left(1 \mathrm{~kg}^{-1} \mathrm{~min}^{-1}\right)^{\mathrm{b}}$ & $175.49 \pm 22.92$ & 13.06 & $138.66 \pm 6.56$ & 4.73 \\
\hline$V_{\mathrm{a}} / F\left(1 \mathrm{~kg}^{-1}\right)$ & $17.98 \pm 6.72$ & 37.38 & $17.09 \pm 2.61$ & 15.29 \\
\hline$V_{\mathrm{ss}} / F\left(1 \mathrm{~kg}^{-1}\right)^{\mathrm{b}}$ & $15.07 \pm 2.36$ & 15.63 & $12.58 \pm 0.45$ & 3.58 \\
\hline$t_{1 / 2 \lambda}(\min )^{\mathrm{a}}$ & $69.75 \pm 20.02$ & 28.70 & $85.41 \pm 12.35$ & 14.45 \\
\hline AUMC $\left(\mu \mathrm{g} \min ^{2} \mathrm{ml}^{-1}\right)^{\mathrm{a}}$ & $9962.3 \pm 1767.5$ & 17.74 & $13,181.8 \pm 1542.2$ & 11.70 \\
\hline $\operatorname{MRT}(\min )^{a}$ & $85.98 \pm 7.98$ & 9.28 & $90.98 \pm 6.77$ & 7.45 \\
\hline MAT (min) & 59.02 & & 64.02 & \\
\hline$F(\%)$ & 98.89 & & 123.57 & \\
\hline
\end{tabular}

$\lambda$ - elimination rate constant; AUC - area under the plasma concentration-time curve; $C_{\max }-$ maximum plasma levodopa concentration; $t_{\max }-$ time to reach maximum concentration; $\mathrm{Cl} / \mathrm{F}$ - clearance; $V_{\mathrm{a}} / \mathrm{F}$ - volume of area; $V_{\mathrm{ss}} / \mathrm{F}$ - volume of distribution at steady state; $t_{1 / 2 \lambda}$ - half-life associated with the $\lambda$ phase; AUMC - area under the first moment curve; MRT - mean absorption time; $F(\%)$ - fraction of levodopa absorbed.

a Significant differences between day 1 and day 7 ( $t$-test, $P \leq 0.05$ ).

b Significant differences between day 1 and day 7 (Wilcoxon test, $P \leq 0.05$ ).

\section{Results}

\subsection{7-day group}

Fig. 1 shows the plots as a function of time of individual plasma levodopa concentrations obtained on days 1 and 7 from animals (Group 1) after oral administration of $20: 5 \mathrm{mg} / \mathrm{kg}$ levodopa + carbidopa with biperiden $(100 \mu \mathrm{g} / \mathrm{kg})$. The mean plasma levodopa concentrations obtained are shown in Fig. 2.

The pharmacokinetic parameters calculated after non-compartmental analysis are summarized in Table 1 and Table 2 gives the values of $C_{\min }$ and $C_{\max }$.

When levodopa + carbidopa was administered with $100 \mu \mathrm{g} / \mathrm{kg}$ of biperiden over 7 days, the mean value of AUC obtained for levodopa increased by $25 \%$ from day $1\left(115.6 \mu \mathrm{g} \mathrm{min} \mathrm{ml}^{-1}\right)$ to day 7 $\left(144.5 \mu \mathrm{g} \mathrm{min} \mathrm{ml}^{-1}\right)$, and the difference was significant. $C_{\max }$ increased progressively with treatment duration $\left(1.73 \mu \mathrm{g} \mathrm{ml} l^{-1}\right.$ on day 1 and $1.99 \mu \mathrm{g} \mathrm{ml}^{-1}$ on day 7 ) and was $15 \%$ higher on day 7 than on day 1 $(P<0.05)$. In an assessment of the data obtained for $C_{\max }$ through the intermediate days, we found significant differences between day 1 and the other sampling days $(3,5$, and 7$)$. $C_{\min }$ was $24 \%$ higher on day 7 in comparison to day 3 ( $5.25 \mu \mathrm{g} \mathrm{ml}^{-1}$ on day 3 and $6.51 \mu \mathrm{g} \mathrm{ml}^{-1}$ on day 7 ) with significant differences between days 3 and 5 and between days 3 and 7. Significant differences were also found for the rest of the pharmacokinetic parameters calculated between days 1 and 7, except for $\lambda$ and $V_{a}$

Table 2

Values of $C_{\min }$ and $C_{\max }(\mathrm{ng} / \mathrm{ml})$ obtained after oral administration of $20: 5 \mathrm{mg} / \mathrm{kg}$ levodopa/carbidopa and biperiden $(100 \mu \mathrm{g} / \mathrm{kg})$ for 7 days to rabbits $(n=6)$.

\begin{tabular}{llcr}
\hline & & $\bar{X} \pm s(\mathrm{ng} / \mathrm{ml})$ & CV (\%) \\
\hline$C_{\min }(0 \mathrm{~min})$ & Day 3 & $5.25 \pm 0.48$ & 9.16 \\
& Day 5 & $6.48 \pm 1.14$ & 17.61 \\
& Day 7 $^{\mathrm{b}}$ & $6.51 \pm 1.08$ & 16.65 \\
$C_{\max }(20 \mathrm{~min})$ & Day 1 & $1729.60 \pm 87.67$ & 5.07 \\
& Day 3 $^{\mathrm{a}}$ & $1975.58 \pm 201.47$ & 10.20 \\
& Day 5 $^{\mathrm{a}}$ & $2007.59 \pm 167.06$ & 8.32 \\
& Day 7 & $1992.99 \pm 164.27$ & 8.24 \\
\hline
\end{tabular}

Significant differences: a with day $1 ;{ }^{\mathrm{b}}$ with day 3 (Duncan test, $P \leq 0.05$ ). One way ANOVA.

$C_{\max }$ - maximum plasma levodopa concentration; $C_{\min }-$ minimum plasma levodopa concentration (before levodopa administration). 

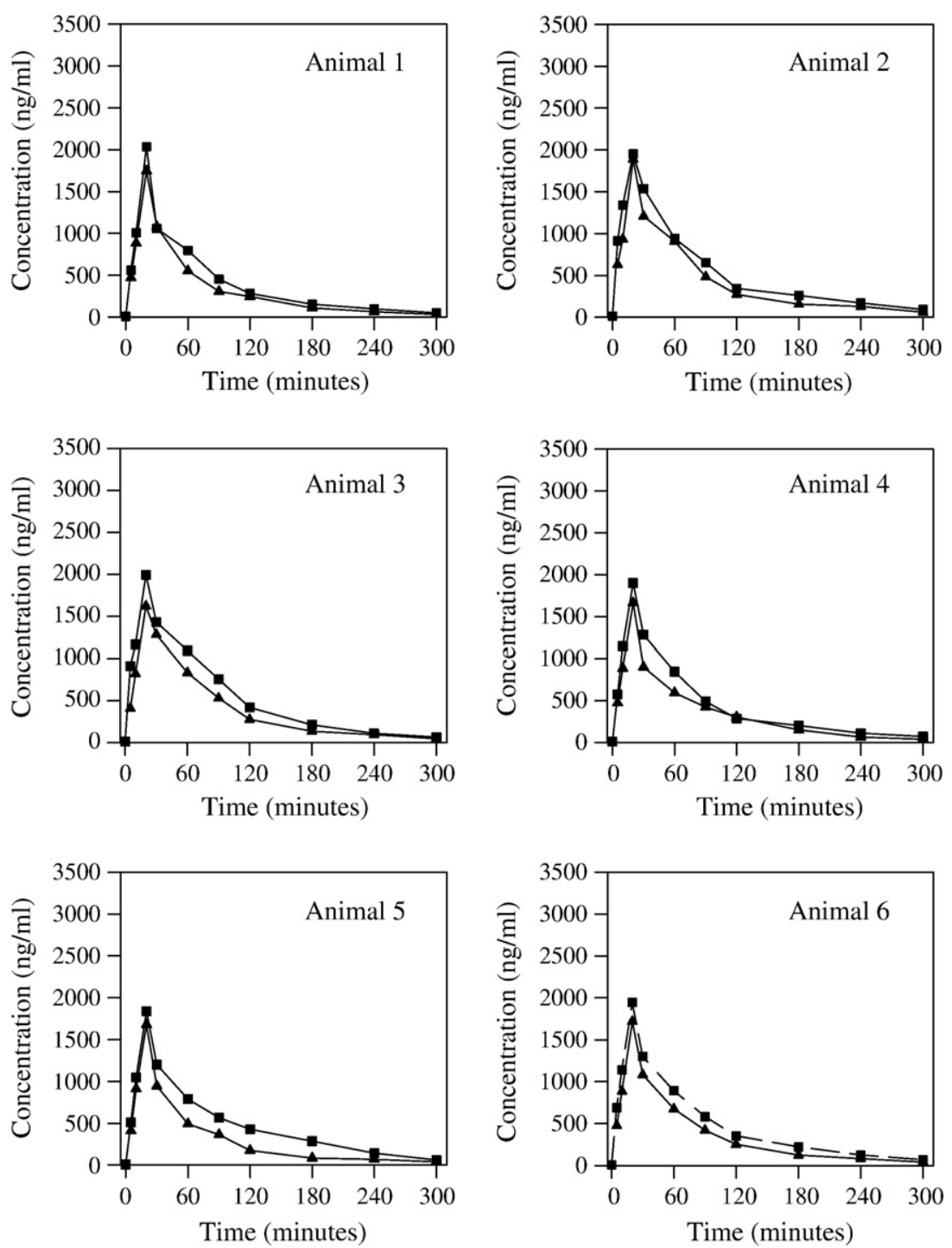

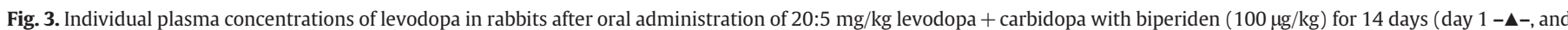
day $14-\mathbf{-}-)$.

\subsection{4-day group}

Fig. 3 includes the plots as a function of time of individual plasma levodopa concentrations corresponding to days 1 and 14 (Group 2) and Fig. 4 the mean plasma levodopa concentrations obtained.

The pharmacokinetic parameters calculated after non-compartmental analysis are summarized in Table 3 and Table 4 gives the values of $C_{\min }$ and $C_{\max }$.

When the drugs were administered for 14 days, the increase in AUC $\left(110.5 \mu \mathrm{g} \mathrm{min} \mathrm{ml}^{-1}\right.$ on day 1 and $147.3 \mu \mathrm{g} \mathrm{min} \mathrm{ml}^{-1}$ on day 14$)$ was $33.4 \%$ on day 14 (significantly different from day 1 ). Similarly, $C_{\max }\left(1.72 \mu \mathrm{g} \mathrm{ml}^{-1}\right.$ on day 1 and $1.94 \mu \mathrm{g} \mathrm{ml} \mathrm{m}^{-1}$ on day 14$)$ was $12.8 \%$ higher after 14 days of treatment (significant differences). $C_{\min }$ increased more than $C_{\max }$ with the duration of the treatment ( $5.95 \mu \mathrm{g} \mathrm{ml}^{-1}$ on day 3 and $8.77 \mu \mathrm{g} \mathrm{ml}^{-1}$ on day 14 ), an increase of $47.4 \%$ by day 14 . Significant differences were identified for comparisons of all the data obtained for $C_{\min }$, except for values from days 11 and 14 .

\subsection{Comparison day 7 and day 14}

We found no significant differences for any pharmacokinetic parameters when comparing values obtained on day 7 and day 14 .
However, mean plasma concentrations of levodopa at the different sampling times were always higher on day 14 of treatment than on day 7, except at four time points at which values were slightly lower:

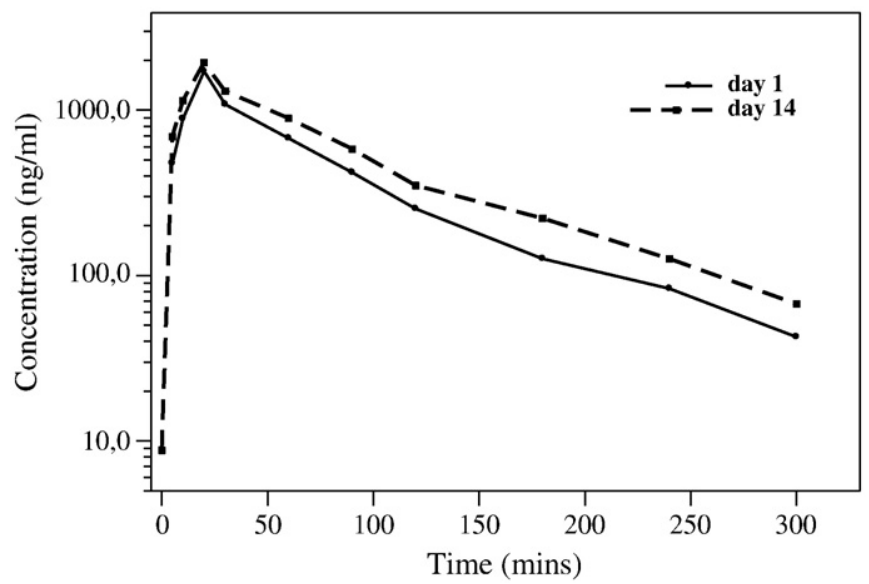

Fig. 4. Mean plasma concentrations of levodopa in rabbits after oral administration of $20: 5 \mathrm{mg} / \mathrm{kg}$ levodopa + carbidopa with biperiden $(100 \mu \mathrm{g} / \mathrm{kg})$ for 14 days. 
Table 3

Pharmacokinetic parameters obtained by non-compartmental analysis in rabbits $(n=6)$ after oral administration of $20: 5 \mathrm{mg} / \mathrm{kg}$ levodopa/carbidopa and biperiden $(100 \mu \mathrm{g} / \mathrm{kg})$ for 14 days.

\begin{tabular}{|c|c|c|c|c|}
\hline \multirow[t]{2}{*}{ Parameters } & \multicolumn{2}{|l|}{ Day 1 of 14} & \multicolumn{2}{|l|}{ Day 14} \\
\hline & $\bar{X} \pm s$ & CV (\%) & $\bar{X} \pm s$ & CV (\%) \\
\hline$\lambda\left(\min ^{-1}\right)$ & $0.0097 \pm 0.0011$ & 11.97 & $0.0101 \pm 0.0018$ & 17.98 \\
\hline AUC $\left(\mu \mathrm{g} \min \mathrm{ml}^{-1}\right)^{\mathrm{a}}$ & $110.45 \pm 14.72$ & 13.33 & $147.32 \pm 16.309$ & 11.06 \\
\hline$C_{\max }\left(\mu \mathrm{g} \mathrm{ml}^{-1}\right)^{\mathrm{a}}$ & $1.72 \pm 0.09$ & 5.43 & $1.94 \pm 0.07$ & 3.58 \\
\hline$t_{\max }(\min )$ & $20.00 \pm-$ & - & $20.00 \pm-$ & - \\
\hline $\mathrm{Cl} / F\left(1 \mathrm{~kg}^{-1} \mathrm{~min}^{-1}\right)^{\mathrm{a}}$ & $183.70 \pm 23.79$ & 12.95 & $137.20 \pm 15.69$ & 11.43 \\
\hline$V_{\mathrm{a}} / F\left(1 \mathrm{~kg}^{-1}\right)$ & $19.27 \pm 4.55$ & 23.63 & $13.89 \pm 2.67$ & 19.24 \\
\hline$V_{\mathrm{ss}} / F\left(1 \mathrm{~kg}^{-1}\right)^{\mathrm{a}}$ & $15.76 \pm 1.78$ & 11.30 & $12.93 \pm 1.23$ & 9.55 \\
\hline$t_{1 / 2 \lambda}(\min )^{\mathrm{a}}$ & $72.29 \pm 10.09$ & 13.96 & $70.39 \pm 11.45$ & 16.27 \\
\hline AUMC $\left(\mu \mathrm{g} \min ^{2} \mathrm{ml}^{-1}\right)^{\mathrm{a}}$ & $9544.6 \pm 1664.1$ & 17.44 & $13,957.4 \pm 2010.3$ & 14.40 \\
\hline $\operatorname{MRT}(\min )^{a}$ & $86.10 \pm 4.75$ & 5.52 & $94.50 \pm 5.48$ & 5.79 \\
\hline MAT (min) & 59.14 & & 67.54 & \\
\hline$F(\%)$ & 94.45 & & 125.98 & \\
\hline
\end{tabular}

$\lambda$ - elimination rate constant; AUC - area under the plasma concentration-time curve; $C_{\max }$ - maximum plasma levodopa concentration; $t_{\max }$ - time to reach maximum concentration; $\mathrm{Cl} / F$ - clearance; $V_{\mathrm{a}} / F-$ volume of area; $V_{\mathrm{ss}} / F$ - volume of distribution at steady state; $t_{1 / 2 \lambda}$ - half-life associated with the $\lambda$ phase; AUMC - area under the first moment curve; MRT - mean absorption time; $F(\%)$-fraction of levodopa absorbed.

a Significant differences between day 1 and day 14 ( $t$-test, $P \leq 0.05$ ).

$20 \mathrm{~min}$ (1993 vs $1943 \mathrm{ng} / \mathrm{ml}$ ); $30 \mathrm{~min}$ (1352 vs $1301 \mathrm{ng} / \mathrm{ml}$ ); $90 \mathrm{~min}$ (626 vs $583 \mathrm{ng} / \mathrm{ml}$ ) and $120 \mathrm{~min}$ (396 vs $351 \mathrm{ng} / \mathrm{ml}$ ).

\section{Discussion}

In this study, we evaluated the influence of slowed gastrointestinal motility on the pharmacokinetics of levodopa/carbidopa in rabbits over 7 or 14 days. Gastrointestinal motility was reduced by oral biperiden administration. To verify the stabilization of levodopa concentrations, we administered the treatment for two different periods of time, 7 or 14 days.

Most antiparkinsonian drugs are delivered orally; therefore, their rate of absorption from the gastrointestinal tract is important in achieving a beneficial clinical effect. One of the important factors affecting the absorption rate from the gastrointestinal tract is the stomach emptying rate (Hardoff et al., 2001). Thus, delayed gastric emptying and, consequently, delayed levodopa arrival at intestinal absorptive sites can cause erratic drug responses. Retention of levodopa in the stomach also increases its exposure to the dopa decarboxylase present in the gastric mucosa; this enzyme can convert the levodopa to dopamine, rendering it unavailable for intestinal absorption (Pfeiffer, 2003). These absorptive vagaries may constitute one mechanism for the development of motor fluctuations in

\section{Table 4}

Values of $C_{\min }$ and $C_{\max }(\mathrm{ng} / \mathrm{ml})$ obtained after oral administration of $20: 5 \mathrm{mg} / \mathrm{kg}$ levodopa/carbidopa and biperiden $(100 \mu \mathrm{g} / \mathrm{kg})$ for 14 days to rabbits $(n=6)$.

\begin{tabular}{llcc}
\hline & & $\bar{X} \pm s(\mathrm{ng} / \mathrm{ml})$ & CV (\%) \\
\hline$C_{\min }(0 \mathrm{~min})$ & Day 3 & $5.95 \pm 1.45$ & 24.40 \\
& Day 6 & $6.61 \pm 1.49$ & 22.46 \\
& Day 9 ${ }^{\mathrm{b}, \mathrm{c}}$ & $7.07 \pm 1.75$ & 24.71 \\
& Day 11 & 25.62 \\
& Day 14,c, & $7.95 \pm 2.04$ & 23.22 \\
$C_{\max }(20 \mathrm{~min})$ & Day 1 & $8.77 \pm 2.04$ & 5.43 \\
& Day 3 & $1719.57 \pm 93.39$ & 7.41 \\
& Day 6 & $1568.96 \pm 116.32$ & 6.75 \\
& Day 9 & $1629.72 \pm 110.02$ & 7.79 \\
& Day 11 & $1705.15 \pm 132.76$ & 4.14 \\
& Day 14,c,d & $1837.12 \pm 75.98$ & 3.58 \\
\hline
\end{tabular}

Significant differences: ${ }^{\text {a }}$ with day $1 ;{ }^{\mathrm{b}}$ with day $3 ;{ }^{\mathrm{c}}$ with day $6 ;{ }^{\mathrm{d}}$ with day 9 (Duncan test, $P \leq 0.05)$. One way ANOVA.

$C_{\max }$ - maximum plasma levodopa concentration; $C_{\min }-$ minimum plasma levodopa concentration (before levodopa administration). individuals with Parkinson's disease (Djaldetti et al., 1996; Kurlan et al., 1988).

The mean values obtained for the different pharmacokinetic parameters on day 1 in both groups ( 7 and 14 days of treatment) were very similar.

Previous studies were carried out administering levodopa/carbidopa in a single dose (Fernandez et al., 2005) and after repeated administration (for 7 or 14 days) to rabbits with normal gastrointestinal function (Fernandez et al., in press). The repeated administration was carried out to stabilize levodopa concentrations, and higher values for AUC, $C_{\max }$ and $C_{\min }$ were obtained after 7 or 14 days (Fernandez et al., in press).

The values obtained for AUC on day 1 of treatment in this study were lower than those obtained after administration of the same dose of levodopa/carbidopa to rabbits with normal gastrointestinal function after single (Fernandez et al., 2005) or repeated administration (Fernandez et al., in press). However, after 7 or 14 days of treatment, these differences had diminished a great deal: the value for

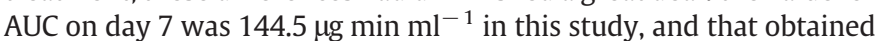
by Fernandez et al. (in press) was $150.4 \mu \mathrm{g} \mathrm{min} \mathrm{ml}^{-1}$. Similarly, AUC on day 14 in the present study was $147.3 \mu \mathrm{g} \mathrm{min} \mathrm{ml}{ }^{-1}$ and $157.5 \mu \mathrm{g} \mathrm{min} \mathrm{ml}^{-1}$ in rabbits with normal gastrointestinal motility (Fernandez et al., in press).

The values of $C_{\max }$ showed more important differences. In this study, on day 1 of treatment $\left(1.73 \mu \mathrm{g} \mathrm{ml}^{-1}\right.$ day 1 of 7 , and $1.72 \mu \mathrm{g} \mathrm{ml} \mathrm{m}^{-1}$ day 1 of 14), this parameter was lower than that obtained in a previous study when gastrointestinal motility was not slowed after a single administration of the drugs $\left(2.74 \mu \mathrm{g} \mathrm{ml}^{-1}\right.$, Fernandez et al., 2005) as well as after repeated administration: $2.47 \mu \mathrm{g} \mathrm{ml}^{-1}$ day 1 of 7 , and $2.55 \mu \mathrm{g} \mathrm{ml}^{-1}$ day 1 of 14 (Fernandez et al., in press). On day 7 of treatment, the values of $C_{\max }$ in the current work were much lower than in the previous work (normal gastrointestinal motility): $1.99 \mu \mathrm{g} \mathrm{ml}^{-1}$ vs $2.70 \mu \mathrm{g} \mathrm{ml}^{-1}$ (Fernandez et al., in press). The results on day 14 were very similar: $1.94 \mu \mathrm{g} \mathrm{ml}^{-1}$ vs $2.71 \mu \mathrm{g} \mathrm{ml}^{-1}$ (Fernandez et al., in press).

The $t_{\max }$ value obtained in this study (20 min) was the same as that obtained in previous studies carried out in rabbits after a single (Fernandez et al., 2005) or a repeated (Fernandez et al., in press) administration of the same dose of levodopa/carbidopa.

On the other hand, levodopa concentrations at the final sampling times are always higher than those obtained without biperiden in a previous study (Fernandez et al., in press). Thus, in our group of animals treated for 7 days, plasma levels were higher after 90 min on day 1 , and after $120 \mathrm{~min}$ on day 7 . The second group of rabbits presented higher final concentrations after 120 min on day 1 and after 90 min on day 14.

Regarding elimination parameters, the value of $\mathrm{Cl} / \mathrm{F}$ on day 1 of treatment was slightly higher in this study than that obtained when the gastrointestinal motility was normal (Fernandez et al., in press). However, at the end of the treatments ( 7 or 14 days), both values were very similar. On the other hand MRT was always higher in this study.

\section{Conclusions}

Our findings suggest that the gastrointestinal impairment caused by biperiden in rabbits initially diminishes the extent of levodopa absorbed. However, the rate of absorption is not affected in the same way: the value of $t_{\max }$ remains similar with or without biperiden, although final higher concentrations are achieved.

If these findings translate to people, constipation might initially affect the extent of levodopa absorption, although over the course of treatment absorption may achieve normal levels. However, other parameters remained altered throughout treatment, such as $C_{\max }$, $C_{\text {min }}$, and MRT. Thus, it is possible that in humans, gastrointestinal autonomic disorders may contribute to the modifications produced in levodopa pharmacokinetics. Efforts to avoid these modifications may 
improve the effectiveness of levodopa treatment. As several authors have indicated, as the disease progresses, the synaptic dopamine concentrations and clinical effect become strictly dependent on plasma levodopa concentrations, and factors affecting peripheral levodopa pharmacokinetics become critical to the therapeutic response (Nutt, 1987; Contin et al., 1996).

\section{References}

Bredberg, E., Tedroff, J., Aquilonius, S.M., Paalzow, L., 1990. Pharmacokinetics and effects of levodopa in advanced Parkinson's disease. Eur. J. Clin. Pharmacol. 39, 385-389.

Contin, M., Riva, R., Albani, F., Baruzzi, A., 1996. Pharmacokinetic optimisation in the treatment of Parkinson's disease. Clin. Pharmacokinet. 30, 463-481.

Cummings, J., Matheson, L.M., Smyth, J.F., 1990. Method for the determination of gamma-L-glutamyl-L-dihydroxyphenylalanine and its major metabolites L-dihydroxyphenylalanine, dopamine and 3,4-dihydroxyphenylacetic acid by highperformance liquid chromatography with electrochemical detection. J. Chromatogr. 528, 43-53.

Djaldetti, R., Baron, J., Ziv, I., Melamed, E., 1996. Gastric emptying in Parkinson's disease: patients with and without response fluctuations. Neurology 46, 1051-1054.

Edwards, L.L., Quigley, E.M., Pfeiffer, R.E., 1993. Gastrointestinal symptoms in Parkinson's disease: 18 month follow-up study. Mov. Disord. 8, 83-87.

Fernandez, N., Carriedo, D., Sierra, M., Diez, M.J., Sahagun, A., Calle, A., Gonzalez, A., Garcia, J.J., 2005. Hydrosoluble fiber (Plantago ovata husk) and levodopa II: experimental study of the pharmacokinetic interaction in the presence of carbidopa. Eur. Neuropsychopharmacol. 15, 505-509.

Fernandez, N., Prieto, C., Sierra, M., Diez, M.J., Sahagun, A., Gonzalez, A., Garcia, J.J., 2008. Evolution of the bioavailability and other pharmacokinetic parameters of levodopa (with carbidopa) in rabbits. Meth. Find. Exp. Pharmacol. 30, 1-7.
Garcia, J.J., Fernandez, N., Carriedo, D., Diez, M.J., Sahagun, A., Gonzalez, A., Calle, A., Sierra, M., 2005. Hydrosoluble fiber (Plantago ovata husk) and levodopa I: experimental study of the pharmacokinetic interaction. Eur. Neuropsychopharmacol. 15, 497-503.

Gibaldi, M., Perrier, D., 1982. Multicompartment models, Pharmacokinetics, 2nd ed. Marcel Dekker, New York.

Hardoff, R., Saula, M., Tamir, A., Soil, A., Front, A., Badarna, S., Honigman, S., Giladi, N., 2001. Gastric emptying time and gastric motility in patients with Parkinson's disease. Mov. Disord. 16, 1041-1047.

Kempster, P.A., Frankel, J.P., Bovingdon, M., Webster, R., Lees, A.J., Stern, G.M., 1989 Levodopa peripheral pharmacokinetics and duration of motor response in Parkinson's disease. J. Neurol. Neurosurg. Psychiatr. 52, 718-723.

Korczyn, A.D., 1989. Autonomic nervous system screening in patients with early Parkinson's disease. In: Przuntek, H., Riederer, P. (Eds.), Early Diagnosis and Preventive Therapy in Parkinson's Disease. Springer-Verlag, Vienna, pp. 41-48.

Kurlan, R., Rothfield, K.P. Woodward, W.R., Nutt, J.G., Miller, C. Lichter, D., Shoulson, I, 1988. Erratic gastric emptying of levodopa may cause random fluctuations of parkinsonian mobility. Neurology 38, 419-421.

Mouradian, M.M., Heuser, I.J., Baronti, F., Chase, T.N., 1990. Modification of central dopaminergic mechanisms by continuous levodopa therapy for advanced Parkinson's disease. Ann. Neurol. 27, 18-23.

Nutt, J.G., 1987. On-off phenomenon: relation to levodopa pharmacokinetics and pharmacodynamics. Ann. Neurol. 22, 535-540.

Nutt, J.G., Fellman, J.H., 1984. Pharmacokinetics of levodopa. Clin. Neuropharmacol. 7, 35-49.

Nyholm, D., Asmark, H., Gomes-Trolin, C., 2003. Optimizing levodopa pharmacokinetics: intestinal infusion versus oral sustained-release tablets. Clin. Neuropharmacol. 26, 156-163.

Pfeiffer, R.F., 2003. Gastrointestinal dysfunction in Parkinson's disease. Lancet Neurol. 2 , 107-115.

Shoulson, I., Glaubiger, G.A., Chase, T.N., 1975. On-off response. Clinical and biochemical correlations during oral and intravenous levodopa administration in parkinsonian patients. Neurology 25, 1144-1148.

Wilk, J.B., Lash, T.L., 2007. Risk factor studies of age-at-onset in a sample ascertained for Parkinson disease affected sibling pairs: a cautionary tale. Them. Epidemiol. 4, 1-6. 